\title{
GEOTHERMAL RESOURCE ANALYSIS IN THE BIG WOOD RIVER VALLEY, BLAINE COUNTY, IDAHO
}

Leah V. Street

\author{
Idaho Department of Water Resources \\ $1301 \mathrm{~N}$. Orchard street \\ Boise, Idaho 83706
}

\section{DISCLAIMER}

This report was prepared as an account of work sponsored by an agency of the United States Government. Neither the United States Government nor any agency thereof, nor any of their employees, makes any warranty, express or implied, or assumes any legal liability or responsibility for the accuracy, completeness, or usefulness of any information, apparatus, product, or process disclosed, or represents that its use would not infringe privately owned rights. Reference herein to any specific commercial product, process, or service by trade name, trademark, manufacturer, or otherwise does not necessarily constitute or imply its endorsement, recommendation, or favoring by the United States Government or any agency thereof. The views and opinions of authors expressed herein do not necessarily state or reflect those of the United States Government or any agency thereof.

October 1990
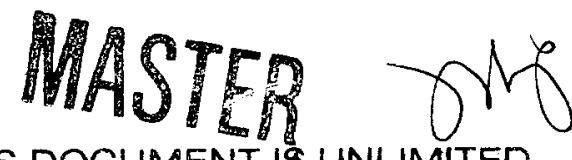


\section{DISCLAIMER}

This report was prepared as an account of work sponsored by an agency of the United States Government. Neither the United States Government nor any agency Thereof, nor any of their employees, makes any warranty, express or implied, or assumes any legal liability or responsibility for the accuracy, completeness, or usefulness of any information, apparatus, product, or process disclosed, or represents that its use would not infringe privately owned rights. Reference herein to any specific commercial product, process, or service by trade name, trademark, manufacturer, or otherwise does not necessarily constitute or imply its endorsement, recommendation, or favoring by the United States Government or any agency thereof. The views and opinions of authors expressed herein do not necessarily state or reflect those of the United States Government or any agency thereof. 


\section{DISCLAIMER}

Portions of this document may be illegible in electronic image products. Images are produced from the best available original document. 


\section{Acknowledgements}

I would like to acknowledge the contributions of the following: Bill Young, Duncan Foley, Larry Dee, and Allen Merritt for their support of and help with this project. I would also like to acknowledge Paul castelin for all of his help and patience. 
GEOTHERMAL RESOURCE ANALYSIS IN THE

BIG WOOD RIVER VALLEY, BLAINE COUNTY, IDAHO

\section{TABLE OF CONTENTS}

ABSTRACT . . . . . . . . . . . . . . . . . ii

INTRODUCTION . . . . . . . . . . . . . . . . . . 1

Purpose and scope ................... 1

Previous Studies . . . . . . . . . . . . . . 1

REGIONAI GEOLOGIC AND HYDROLOGIC SETTING . . . . . . . . . . . 2

Geology . . . . . . . . . . . . . . . . . . . 2

Topography ........................ 2

Climate ...................... 3

Surface Water .. . . . . . . . . . . . . . . 3

Ground Water ........ . . . . . . . . . . . . 3

General Descriptions of the Thermal Springs and Wells . . 3

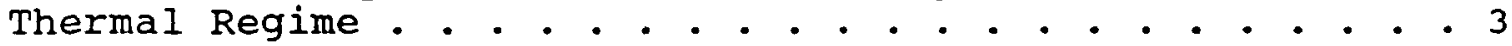

Ore Deposits . . . . . . . . . . . . . . . . . 5

Subsurface Geology obtained from Well Drillers Logs . . 8

Geochemistry of Thermal Systems . . . . . . . . . 8

CHEMICAL CONSTITUENTS AND TYPES OF WATER . . . . . . . . . . 12

Major Constituents . . . . . . . . . . . . . . . . . 12

Source of Fluoride and other Elements . . . . . . . 12

Minor Constituents . . . . . . . . . . . . . . 15

Geothermometry . . . . . . . . . . . . . . 15

Isotopes..................... 16

SUMMARY . . . . . . . . . . . . . . . . 20

SELECTED REFERENCES . . . . . . . . . . . . . . . . 21

PLATE

1. Location Map of the Big Wood River Study Area . . (in pocket)

\section{LIST OF FIGURES}

Figure No.

Page

1. Location map for wells and foundation holes . . . . . . 6

2. Temperature profiles of wells and foundation holes . . . . 7

3. Comparison of isotopic composition of waters . . . . . . . 17

4. Concentration of $\mathrm{D}$ vs. $\mathrm{O}^{18}$. . . . . . . . . . . . . 18 


\section{LIST OF TABLES}

Table No.

$\underline{\text { Page }}$

1. Hot Spring and Well Location Information . . . . . . . . . . 4

2. Analyses of Thermal Springs and Wells . . . . . . . . . . . 9

3. Analyses of Cold Springs . . . . . . . . . . . . . . . . . 11

4. Whole-Rock Analyses of Selected Rocks from the Big Wood River Area . . . . . . . . . . . . . . . . . . . . 13

5. Fluoride in Rocks and Minerals from Central Idaho . . . . 14

6. Deuterium and Oxygen-18 Values . . . . . . . . . . . . . . 19 
A geochemical investigation of both thermal and nonthermal springs in the Wood River area was conducted to determine possible flowpaths, ages of the waters, and environmental implications. Seven thermal springs and five cold springs were sampled for major cations and anions along with arsenic, lithium, boron, deuterium and oxygen-18. Eight rocks, representative of outcrops at or near the thermal occurrences were sampled and analyzed for major and trace elements.

The wood River area hydrothermal springs are dilute $\mathrm{Na}-\mathrm{HCO}_{3}-$ $\mathrm{SiO}_{2}$ type waters. Calculated reservoir temperatures do not exceed $100^{\circ} \mathrm{C}$., except for Magic Hot Springs Landing well $\left(108^{\circ} \mathrm{C}\right.$. with $\mathrm{Mg}$ correction). The isotope data suggest that the thermal water is not derived from present-day precipitation, but from precipitation when the climate was much colder and wetter.

Intrusive igneous rocks of the Idaho batholith have reacted with the hydrothermal fluids at depth. The co-location of the thermal springs and mining districts suggests that the structures acting as conduits for the present-day hydrothermal fluids were also active during the emplacement of the ore bodies. 


\section{INTRODUCTION}

Purpose and scope

This study is a geochemical survey of the hydrothermal fluids and suspected reservoir rocks in the wood River area (Plate 1). A documentation and evaluation of the fluoride contents of the rocks and waters and environmental implications of the thermal fluids were also conducted. The scope of this study includes the following: 1) developing an inventory of thermal springs and wells; 2) sampling the thermal springs and/or wells and selected cold springs for major cations/anions and for $0^{18}$, deuterium, arsenic, lithium and boron; 3) sampling suspected reservoir rocks for major and trace elements including fluoride and 4) completing temperature logs for existing wells.

Previous Studies

Numerous studies of the geology and geothermal resources of the wood River and adjacent areas have been made. Geologic studies have been conducted to investigate mineral deposits (Umpleby and others, 1930; Anderson and Wagner, 1946; Anderson and others, 1950; Hall and others, 1978); individual formations and units (Hall and others, 1974; Sandberg and others, 1975); quadrangles (Batchelder and Hall, 1978) and to compile regional information (Rember and Bennett, 1979). Currently, workers from the U.S. Geological Survey Geologic Division are mapping and assessing the mineralization of the area. The geology of several hot spring sites has been mapped in varying detail by Anderson and Bideganeta (1985); Blackett (1981); Struhsacker and others (1982) and by Leeman (1982). An excellent report on the current mapping and interpretive studies is found in the Guidebook to the Geology of Central and Southern Idaho (1988).

Thermal waters in the study area were first mentioned by Umpleby and others (1930) who discussed Guyer, clarendon and Hailey Hot Springs as well as a deposit of travertine in the Triumph mine area. Regional assessments of the geothermal resources have been made by personnel from the U.S. Geological Survey (Sammel, 1979; Mariner and others, 1983). Personnel from the Idaho Department of Water Resources studied hydrothermal systems in the Camas Prairie area (Mitchell, 1976) and the Wood River drainage (Anderson and Bideganeta, 1985). The wood River area was also included in a statewide summary of geothermal resources conducted by the Idaho Department of Water Resources (Mitchell and others, 1980).

Individual systems that have been investigated are Magic Hot Springs (Struhsacker and others, 1982) and Guyer Hot Springs (Blackett, 1981; Burkett and Litke, 1989). Geochemical studies of the thermal springs were conducted by zeisloft and others (1983) and Foley and others (1983). Foley and street (1985; 1986; 1988) have discussed the nature and occurrence of the thermal resources 
and the elevated fluoride levels, and have prepared a field guide addressing individual spring sites and regional geothermal potential.

REGIONAL GEOLOGIC AND HYDROLOGIC SETTING

Geology

A brief summary of geologic units is given below. Detailed discussions of stratigraphic and structural conditions and references to the geologic environment in the wood River area can be found in Link, et al, 1988 .

sedimentary and extrusive and intrusive igneous rocks are exposed in the study area hot springs and wells. The Paleozoic Milligen, wood River and Dollarhide Formations, which are sandstones, limestones, siltstones, and conglomerates, are found in the vicinity of the hot springs (Hall and others, 1974; Hall, 1985; Link and others, 1987 and 1988; Otto and Turner, 1987; Sandberg and others, 1975; Wavra and others, 1986). Mesozoic and Cenozoic intrusives of the Idaho Batholith and related rocks (Bennett and Knowles, 1985; Johnson and others, 1988) are also exposed in the study area. Cenozoic Challis Volcanics (Hall and McIntyre, 1986) overlie other sedimentary and intrusive rocks. Miocene and Pliocene rhyolites, ash-flow tuffs and ferrolatites found in the Magic Hot springs area (Bonnichsen and others, 1988) are interlayered with and covered by Quaternary basalts from snake River Plain volcanic centers.

The study area is characterized by several episodes of faulting and folding related to regional tectonic events and igneous intrusions. In general, the west side of the wood River valley is more extensively faulted than the east side. Most intrusive rocks, major mining districts and hydrothermal systems are also located west of the Big wood River. The structural control on the deposition of the ore bodies has been described by Umpleby and others (1930); Anderson and others (1950) and Hall and others (1978). Other studies of the structures of the area include thrust faulting (Skipp and Hait, 1977; Skipp, 1987), high angle faulting related to batholith emplacement (Hall and others, 1978), current tectonism (Howard and others, 1978) and low angle normal faulting (Wust, 1986; Link and others, 1987; Otto and Turner, 1987).

Topography

North of the study area in the Idaho Batholith, valleys a few miles wide are flanked by mountains, which in places have elevations of nearly 10,000 feet. In the study area, some elevations exceed 12,000 feet with valleys that are 3 to 10 miles wide. South of the study area, the Snake River Plain has elevations 
ranging from 3,000 to 5,000 feet and is relatively flat except for Mount Bennett ( 6600 feet) and the Picabo Hills (6270 feet).

Climate

The climate in the study area ranges from semiarid in the valleys to subhumid in the mountain ranges. Precipitation is mainly snow and varies from an average annual value of 16.41 inches at the Hailey Ranger station to 38 inches in the mountains (Frenzel, 1989).

The only recorded mean annual air temperatures are in Hailey $\left(43.1^{\circ} \mathrm{F.}\right)$, at an elevation of 5329 feet, and sun valley $\left(37.6^{\circ}\right.$ $\left.F_{.}\right)$, at an elevation of 5791 feet. No records exist for the higher elevations.

Surface Water

Drainage of the study area is by the Big wood River and its tributaries. The Camas Prairie drainage is by Camas Creek and its tributaries. Camas Creek is tributary to the Big Wood River and at their confluence, both are impounded by the Magic Reservoir Dam. The Big Wood River then flows into the snake River.

\section{Groundwater}

Groundwater resources in the study area are found as shallowdepth, cold waters from alluvial aquifers or basalt flows (Smith, 1959; Walton, 1962; Castelin and Chapman, 1972). The majority of the wells in the study area are shallow (less than 100 feet) and are completed in alluvium; however, some are completed in Iimestone or granite. Frenzel (1989) studied the surface and groundwater interaction and effect of development on the upper Big Wood River basin and castelin and winner (1975) studied the impacts of urbanization on water quality.

General Descriptions of the Thermal springs and Wells

Several studies have described the individual hot spring or well sites in detail (Anderson and Bideganeta, 1985; Blackett, 1981; Mitchell, 1976; Mitchell and others, 1980; Struhsacker and others, 1982; and Foley and street, 1988). Table 1 lists the pertinent information for the sites. Locations of the sampled sites are found on the map of the study area, Plate 1.

Thermal Regime

The thermal regime of the snake River Plain has been studied by Brott and others $(1976 ; 1981)$ who reported heat flow values of approximately 70 to 400 milliwatts per square meter for the Camas Prairie, Mt. Bennett Hills and Magic Reservoir areas. A value of 51 milliwatts per square meter was reported from a well northeast 
TABLE 1. HOT SPRING AND WELL LOCATION INFORMATION

\begin{tabular}{|c|c|c|c|c|c|c|}
\hline Site & Location & Temp. ${ }^{\circ} \mathrm{C}$ & $\begin{array}{c}\text { Flow } \\
\text { (gpm) }\end{array}$ & $\begin{array}{c}\text { Elev- } \\
\text { ation } \\
\text { (feet) }\end{array}$ & Use & Remarks \\
\hline
\end{tabular}

Magic Hot Springs

Landing Well

Hailey Hot springs

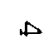

Clarendon Hot springs

O3N $17 \mathrm{E} \quad 27 \mathrm{DCB}$

O4N $17 \mathrm{E} \quad 15 \mathrm{ACC}$

O4N 16E 36ACC

O5N 16E 10DBC

06N $\quad 16 \mathrm{E} \quad 33 \mathrm{CCA}$

Easley Hot Sprlnge

Rusilan John Hot Spring
74.5

0.0

50.0

100

70.5

500

58.5

37.5

68

34.0
Once used

as resort; presently unused.

Once used for heating in Hailey; now unused.

Once used as resort; now unused.

District

space heating 
of Hailey suggesting that the heat flow along the margins of the Plain may be higher than the area north of the Plain.

Adjacent to Guyer Hot springs, temperature profiles in foundation test holes and warm wells, Figures 1 and 2 , show the presence of hot water at depth and not necessarily a uniform thermal gradient. The warm well, D4, is influenced by cold water circulation from the nearby creek. Temperatures recorded at depth do not exceed the temperatures of the fluids issuing at the surface.

The Croesus mine in Scorpion Gulch, near Hailey Hot springs, was reported by Umpleby and others (1930) as being unusually warm. At the 200 foot level a temperature of $13.9^{\circ} \mathrm{C} .\left(57^{\circ} \mathrm{F}.\right)$ was recorded and at the 800 foot level, $33.3^{\circ} \mathrm{C} .\left(92^{\circ} \mathrm{F}.\right)$ was measured, indicating an increase of $0.05^{\circ} \mathrm{F}$./foot. The Minnie Moore Mine, just west of Hailey, reportedly intersected large flows of hot water during tunneling (Guy Jones, personal communication, 1988).

Ore Deposits

The origin of the ore deposits located west of the wood River Valley was studied by Umpleby and others (1930), who concluded that the structures controlling ore deposition and the mineralizing fluids were related to the emplacement of the Idaho Batholith and associated intrusions. Anderson and others (1950) determined that the ore deposition was controlled by the nature of the faulting and not by stratigraphic controls; however, they decided that the ore emplacement was in the early Tertiary. Hall and others (1978) concluded that the ores were formed by hydrothermal systems of meteoric water during the Late cretaceous or early Tertiary. They further suggested that the intrusion of small granitic bodies and the related crustal movements could have acted as conduits for deep circulation of water that leached metals and sulfur from the Paleozoic rocks. The wood River Thrust was hypothesized to have been a principal recharge zone for this hydrothermal system.

To the east of the wood River Mining area is the Muldoon District, a group of lead-silver deposits that is thought to be related to the wood River mineralization (Hall and others, 1978). Three separate hydrothermal systems have been proposed by Hall and others (1979) to be related to separate small plutonic bodies. These three systems are: the Silver Queen - Minnie Moore mine area 1.2 miles west of Bellevue, the Mayflower - Red Elephant mine area 3.4 miles west of Hailey and the Parker-North Star area $2.8 \mathrm{miles}$ east 


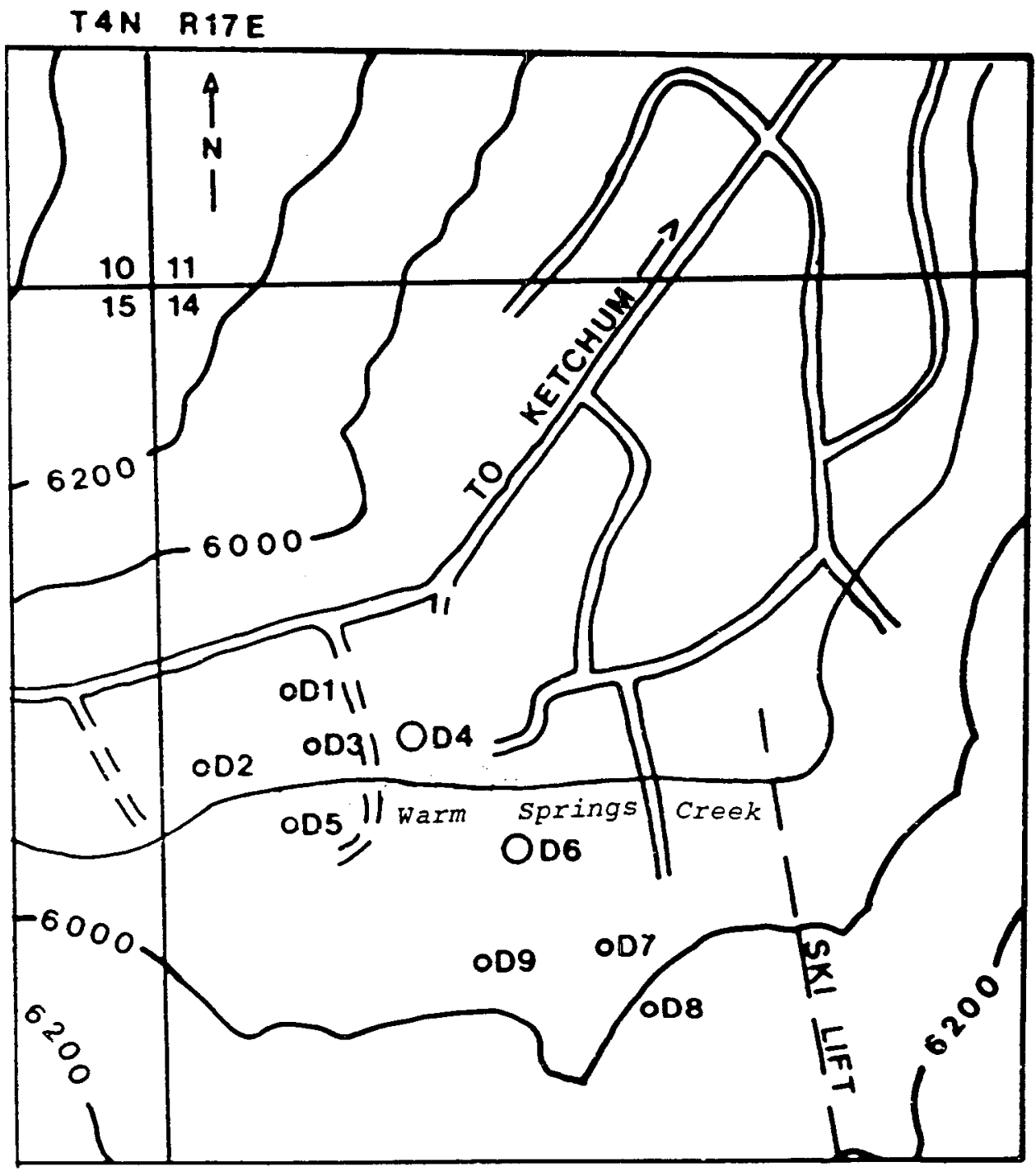

Scale: $1^{\prime \prime}=0.25 \mathrm{mile}$

FIGURE 1. Location map for wells (D4 and D6) and foundation holes (D1-3,5, and 7-9) near Warm Springs

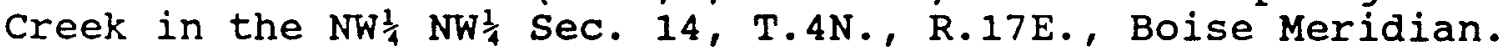
(Based on USGS 7.5-min. Griffin Butte quadrangle) 


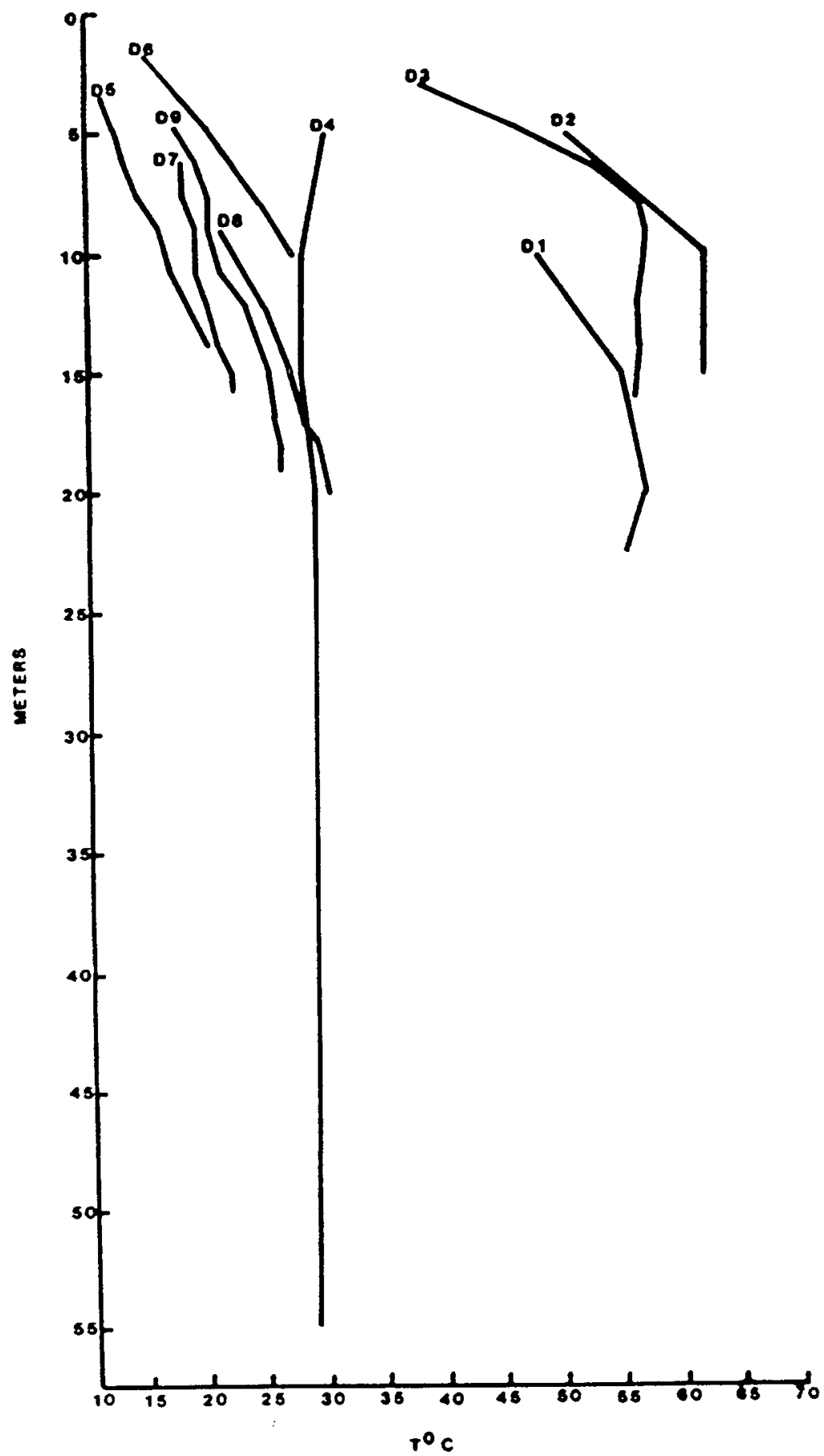

FIGURE 2. Temperature profiles of wells (D4 and D6) and foundation holes (all others) in the NW $\frac{1}{4} N W \frac{1}{4}$ Sec. 14, T.4N., R.17E., Boise Meridian. See Figure 1 for well locations. 
of Ketchum. All mine areas were in domed or arched structures over plutons or on the flanks of plutons. Further, all were located near but under the regional wood River thrust fault.

Faulting associated with emplacement of igneous intrusions can allow deep circulation and heating of meteoric water. The location of the major lead-silver ore bodies and the hot springs on the west side of the valley suggests that this area was more receptive to both mineralization and hydrothermal fluid movement. Anderson, Kiilsgaard and others (1950) noted that broad opened folds commonly grade into regions of tight folding and crumpling in the Triumph Mine area, suggesting that the permeability is indeed low. Umpleby and others (1930) reported the presence of travertine in Elkhorn canyon behind a cold spring. This may indicate the presence of a paleo hot spring; if so, this is the only clue of hot spring activity on the east side of the Wood River Valley.

The geographic relationship of the present hot-spring activity and past ore deposition suggests that thermal fluids may currently be following similar flow-paths, although not driven by magmatic activity, as were past ore-forming fluids.

Subsurface Geology Obtained from Well Driller's Logs

Well data generally confirms the surface geology except in a few notable places. Decomposed granite is encountered in two wells drilled northwest of Ketchum, and granite is found in two wells along Trail Creek Road, northeast of Ketchum. At the surface, rocks of the Wood River Formation are exposed. Wells southeast and southwest of Ketchum encounter limestone at about 70 feet. The area is mapped as Tertiary extrusives. In west Hailey, granite is found at 46 feet and in section 25, along croy creek, wells have been completed in limestone, granite and decomposed granite. These observations were made in more than one well log, suggesting that granite is closer to the surface and is more extensive than shown on current geologic maps.

Geochemistry of Thermal systems

Seven thermal springs and five cold springs were sampled to determine the composition, temperature at depth, flow paths and origin or source of waters (Tables 2 and 3). Major cations and anions were determined along with arsenic, lithium, boron, deuterium and $\mathrm{o}^{18}$. Analyses for $\mathrm{pH}$ and conductance were performed on site. The remaining were determined by the U.S. Geological Survey National water quality Laboratory. 
TABLE 2. ANALYSES OF THERMAL SPRINGS AND WELLS

(All constituents reported in $\mathrm{mg} /($ unless otherwise noted.)

\begin{tabular}{|c|c|c|c|c|c|c|c|c|c|c|c|}
\hline Spring Name and Location & $\begin{array}{l}\text { Sample } \\
\text { Date }\end{array}$ & $\begin{array}{c}\text { Na- } \mathrm{K}-\mathrm{Ca} \\
\text { geother } \\
\text { mometer } \\
\text { temp } \\
\end{array}$ & $\begin{array}{c}\text { Specific } \\
\text { conduct- } \\
\text { ance } \\
(\mu \text { mhos }) \\
\end{array}$ & $\mathrm{pH}$ & $\begin{array}{l}\text { Water } \\
\text { temp., } \\
{ }^{\circ} \mathrm{C} .\end{array}$ & $\begin{array}{l}\text { Calcium } \\
\text { (Ca) }\end{array}$ & $\begin{array}{l}\text { Magnesium } \\
(\mathrm{Mg})\end{array}$ & $\begin{array}{l}\text { Sodium } \\
\text { (Na) }\end{array}$ & $\begin{array}{l}\text { Potassium } \\
\text { (K) }\end{array}$ & $\begin{array}{c}\text { Field } \\
\text { Alk. os } \\
\mathrm{CaCO}_{3}\end{array}$ & $\begin{array}{l}\text { Sulfate } \\
\left(\mathrm{SO}_{4}\right)\end{array}$ \\
\hline $\begin{array}{l}\text { Russian John Hot spring } \\
06 \mathrm{~N} 16 \mathrm{E} 33 \mathrm{CCB} 1 \mathrm{~S}\end{array}$ & $5 / 03 / 88$ & $53^{\circ} \mathrm{C}$ & 324 & 9.2 & 34.0 & 2.1 & 0.06 & 68 & .60 & 78 & 47 \\
\hline $\begin{array}{l}\text { Easley Hot Spring } \\
\text { O5N 16E } 10 \mathrm{CBC} 1 \mathrm{~S}\end{array}$ & $6 / 02 / 88$ & $60^{\circ} \mathrm{C}$ & 339 & 9.6 & 37.5 & 1.9 & 0.05 & 68 & .70 & 68 & 49 \\
\hline $\begin{array}{l}\text { Warfield Hot Spring } \\
\text { O4N 16E 36AAC1S }\end{array}$ & $6 / 02 / 88$ & $90^{\circ} \mathrm{C}$ & 324 & 9.1 & 58.5 & 2.1 & 0.03 & 69 & 1.90 & 80 & 38 \\
\hline $\begin{array}{l}\text { Guyer Hot spring } \\
04 \mathrm{~N} 17 \mathrm{E} 15 \mathrm{AAC} 1 \mathrm{~S}\end{array}$ & $5 / 03 / 88$ & $94^{\circ} \mathrm{C}$ & 411 & 9.1 & 70.5 & 2.3 & 0.01 & 88 & 2.10 & 78 & 76 \\
\hline $\begin{array}{l}\text { Clarendon Hot Spring } \\
\text { O3N 17E 27DCB1S }\end{array}$ & $5 / 11 / 88$ & $88^{\circ} \mathrm{C}$ & 387 & 9.1 & 50.0 & 2.0 & $<0.01$ & 79 & 1.70 & 77 & 52 \\
\hline $\begin{array}{l}\text { Halley Hot Spring } \\
02 \mathrm{~N} 18 \mathrm{E} 18 \mathrm{DBB} 1 \mathrm{~S}\end{array}$ & $5 / 11 / 88$ & $82^{\circ} \mathrm{C}$ & 326 & 9.6 & 60.0 & 2.1 & 0.05 & 69 & 1.50 & 78 & 45 \\
\hline $\begin{array}{l}\text { Magic Hot Springs Landing } \\
01 \mathrm{~S} 17 \mathrm{E} 23 \mathrm{AAB} 1 \text { (Well) }\end{array}$ & $4 / 14 / 88$ & $\begin{array}{l}187^{\circ} \mathrm{C} \\
\left(108^{\circ} \mathrm{C} .\right.\end{array}$ & 400 & 6.6 & 74.5 & 2.0 & 1.40 & 320 & 20.00 & 610 & 51 \\
\hline
\end{tabular}

* with Mg correction (Fournier and Potter, 1978) 
TABLE 2. ANALYSES OF THERMAL SPRINGS AND WELLS (CONT'D)

(All constituents reported in mg/l unless otherwise noted.)

\begin{tabular}{|c|c|c|c|c|c|c|c|c|c|c|c|}
\hline Spring Name and Location & $\begin{array}{l}\text { Chloride } \\
\text { (CL) }\end{array}$ & $\begin{array}{l}\text { Fluoride } \\
(F)\end{array}$ & $\begin{array}{l}\text { silica } \\
\left(\mathrm{SiO}_{2}\right)\end{array}$ & $\begin{array}{l}\text { Dissolved } \\
\text { solids, } \\
\text { calculated }\end{array}$ & $\begin{array}{c}\text { Nitrate } \\
\text { plus } \\
\text { nitrite } \\
\text { as } \mathrm{N} \\
\left(\mathrm{NO}_{2}+\mathrm{NO}_{3}\right) \\
\end{array}$ & $\begin{array}{l}\text { Phospho } \\
\text {-rus, } \\
\text { total } \\
\text { as P }\end{array}$ & $\begin{array}{c}\text { Arsenic } \\
(\text { As }) \\
(\mu g / l)\end{array}$ & $\begin{array}{c}\text { Boron } \\
(B) \\
(\mu g / l)\end{array}$ & $\begin{array}{l}\text { Lithium } \\
(L i) \\
(\mu g / L)\end{array}$ & $\begin{array}{l}\text { Hardness, } \\
\text { total as } \\
\mathrm{CaCO}_{3}\end{array}$ & $\begin{array}{c}\text { SAR } \\
\text { (sodium } \\
\text { adsorp- } \\
\text { tion } \\
\text { ratio) } \\
\end{array}$ \\
\hline $\begin{array}{l}\text { Russian John Hot } \\
\text { Spring } \\
\text { O6N 16E 33CCB1s }\end{array}$ & 6.5 & 14.0 & 54 & 239 & $<0.100$ & $<0.010$ & $<1$ & 150 & 160 & 5 & 13 \\
\hline $\begin{array}{l}\text { Easley Hot Spring } \\
\text { 05N } 16 \mathrm{E} \text { 10CBC1S }\end{array}$ & 7.8 & 3.1 & 54 & 225 & $<0.100$ & 0.070 & $<1$ & 170 & 150 & 5 & 14 \\
\hline $\begin{array}{l}\text { Warfield Hot Spring } \\
04 \mathrm{~N} 16 \mathrm{E} \text { 36AACIS }\end{array}$ & 10.0 & 3.1 & 94 & 266 & $<0.100$ & 0.090 & 2 & 100 & 170 & 5 & 14 \\
\hline $\begin{array}{l}\text { Guyer Hot Spring } \\
\text { O4N 17E 15AAC1S }\end{array}$ & 11.0 & 15.0 & 80 & 347 & $<0.100$ & 0.010 & $<1$ & 250 & 150 & 30 & 7 \\
\hline $\begin{array}{l}\text { Clarendon Hot spring } \\
03 \mathrm{~N} 17 \mathrm{E} 27 \mathrm{DCB} 1 \mathrm{~S}\end{array}$ & 19.0 & 17.0 & 76 & - & $<0.100$ & 0.010 & $<1$ & 160 & 110 & - & - \\
\hline $\begin{array}{l}\text { Hailey Hot Spring } \\
02 \mathrm{~N} 18 \mathrm{E} \text { 18DBB1S }\end{array}$ & 11.0 & 17.0 & 83 & 276 & $<0.100$ & $<0.010$ & 1 & 100 & 95 & 5 & 14 \\
\hline $\begin{array}{l}\text { Magic Hot Springs } \\
\text { Landing Well }\end{array}$ & 79.0 & 11.0 & 98 & 953 & $<0.100$ & 0.010 & 4 & 1100 & 1300 & 56 & 20 \\
\hline
\end{tabular}

Landing Well

OIS 17E 23AABI 
TABLE 3. ANALYSES OF COLD SPRINGS

(All constituents reported in $\mathrm{mg} / \mathrm{l}$, unless otherwise noted)

\begin{tabular}{|c|c|c|c|c|c|c|c|c|c|c|c|c|}
\hline $\begin{array}{l}\text { Spring Name and } \\
\text { Location }\end{array}$ & $\begin{array}{c}\text { Sample } \\
\text { date }\end{array}$ & $\begin{array}{c}\text { Specific } \\
\text { conduct- } \\
\text { ance, } \\
\text { ( } \mu \text { mhos) }\end{array}$ & $\begin{array}{c}\text { pH } \\
\text { (field) }\end{array}$ & $\begin{array}{l}\text { Water } \\
\text { temp.: } \\
\left({ }^{\circ} \mathrm{C} .\right)\end{array}$ & $\begin{array}{l}\text { Calcium } \\
\text { (Ca) }\end{array}$ & $\begin{array}{l}\text { Magnesium } \\
\quad(\mathrm{Mg})\end{array}$ & $\begin{array}{l}\text { Sodium } \\
\text { (Na) }\end{array}$ & $\begin{array}{l}\text { Potassium } \\
\quad(\mathrm{K})\end{array}$ & $\begin{array}{l}\text { Field } \\
\text { Alk. as } \\
\mathrm{CaCO}_{3}\end{array}$ & $\begin{array}{l}\text { Sulfate } \\
\left(\mathrm{SO}_{4}\right)\end{array}$ & $\begin{array}{l}\text { Chloride } \\
\text { (Cl) }\end{array}$ & $\begin{array}{l}\text { Fluoride } \\
\text { (F) }\end{array}$ \\
\hline $\begin{array}{l}\text { Billingsley Cold Spring } \\
\text { O1N } 21 \mathrm{E} 148001 \mathrm{~S} \\
\text { Elev. } 6040\end{array}$ & $5 / 10 / 89$ & 70 & 6.48 & 10.0 & 6.3 & 1.5 & 5.5 & 2.6 & 26 & 2.0 & 3.4 & 0.10 \\
\hline $\begin{array}{l}\text { Forest Service Spríng } \\
\text { O4N 16E } 280 \text { AC1S } \\
\text { Elev. } 6520\end{array}$ & $6 / 02 / 88$ & 288 & 7.60 & 12.5 & 43.0 & 12.0 & 2.6 & 1.1 & 140 & 9.5 & 1.1 & 0.6 \\
\hline $\begin{array}{l}\text { Triumph Spring } \\
\text { O4N } 18 E 26 B 8 C 15 \\
\text { Elev. } 6560\end{array}$ & $5 / 11 / 88$ & 197 & 7.90 & 8.0 & 30.0 & 3.7 & 6.8 & 0.70 & 92 & 3.7 & 2.8 & 0.30 \\
\hline $\begin{array}{l}\text { Headquarters Spring } \\
\text { 6N 17E 330CA1S } \\
\text { Elev. } 6520\end{array}$ & $5 / 11 / 88$ & 331 & 8.00 & 7.0 & 58.0 & 9.3 & 1.2 & 0.40 & 166 & 8.2 & 0.5 & 0.40 \\
\hline \multirow[t]{2}{*}{$\begin{array}{l}\text { Lambs Gulch Spring } \\
\text { O2N 18E } 188 B A 1 S \\
\text { Elev. } 5540\end{array}$} & $5 / 11 / 88$ & 311 & 7.40 & 8.5 & 54.0 & 8.7 & 7.3 & 0.60 & 139 & 36.0 & 2.1 & 0.30 \\
\hline & & & $\begin{array}{l}\mathrm{LE} 3 . \\
\text { (All co }\end{array}$ & $\begin{array}{l}\text { ANAI } \\
\text { ituents }\end{array}$ & $\begin{array}{l}\text { ES OF } \\
\text { ported if }\end{array}$ & $\begin{array}{l}\text { COLD SI } \\
\mathrm{mg} / \mathrm{l} \text {, unles }\end{array}$ & NGS & $\begin{array}{l}\left.\operatorname{CONT}^{\prime} \mathrm{D}\right) \\
\text { oted) }\end{array}$ & & & & \\
\hline
\end{tabular}

\begin{tabular}{|c|c|c|c|c|c|c|c|c|c|c|}
\hline Spring Name and Location & $\begin{array}{l}\text { silica } \\
\left(\mathrm{SiO}_{2}\right)\end{array}$ & $\begin{array}{l}\text { Dissolved } \\
\text { solids } \\
\text { calculated }\end{array}$ & $\begin{array}{c}\text { Nitrate } \\
\text { plus } \\
\text { nitrite } \\
\text { as } \mathrm{N} \\
\left(\mathrm{NO}_{2}+\mathrm{NO}_{3}\right) \\
\end{array}$ & $\begin{array}{l}\text { Phosphorus, } \\
\text { total as P }\end{array}$ & $\begin{array}{c}\text { Arsenic } \\
(\text { As }) \\
(\mu \mathrm{g} / \mathrm{l})\end{array}$ & $\begin{array}{l}\text { Boron } \\
(B) \\
(\mu g / l)\end{array}$ & $\begin{array}{l}\text { Lithium } \\
(L i) \\
(\mu g / l)\end{array}$ & $\begin{array}{l}\text { Hardness, } \\
\text { total as } \\
\mathrm{CaCO}_{3}\end{array}$ & $\begin{array}{l}\text { SAR } \\
\text { (sodium } \\
\text { adsorp- } \\
\text { tion } \\
\text { ratio) } \\
\end{array}$ & $\begin{array}{l}\text { Sodium } \\
(\%)\end{array}$ \\
\hline $\begin{array}{l}\text { Bill ingsley Cold Spring } \\
\text { 01N } 21 \mathrm{E} 14 \mathrm{B00} 1 \mathrm{~S} \\
\text { Elev. } 6040\end{array}$ & 40.0 & 78 & 0.220 & 0.05 & $<1$ & 30 & $<4$ & 22 & 0.5 & 32 \\
\hline $\begin{array}{l}\text { Forest Service Spring } \\
04 \mathrm{~N} 16 \mathrm{E} 280 \mathrm{AC} 1 \mathrm{~S} \\
\text { Elev. } 6520\end{array}$ & 9.9 & 166 & 0.430 & 0.64 & $<1$ & $<10$ & 7 & 160 & 0.1 & 3 \\
\hline $\begin{array}{l}\text { Triumph Spring } \\
\text { O4N 18E } 268 B C 1 S \\
\text { Elev. } 6560\end{array}$ & 25.0 & 136 & 1.70 & 0.04 & - & - & - & 90 & 0.3 & 14 \\
\hline $\begin{array}{l}\text { Headquarters Spring } \\
\text { ON } 17 E \text { B } 330 \text { CA1S } \\
\text { Elev. } 6520\end{array}$ & 7.1 & 186 & 0.40 & $<0.01$ & - & - & - & 180 & 0.0 & 1 \\
\hline $\begin{array}{l}\text { Lambs Gulch Spring } \\
\text { O2N 18E 18B8A1S } \\
\text { Elev. } 5540\end{array}$ & 21.0 & 214 & 0.16 & 0.03 & - & - & - & 170 & 0.3 & 8 \\
\hline
\end{tabular}




\section{CHEMICAL CONSTITUENTS AND TYPES OF WATER}

\section{Major Constituents}

The thermal fluids of the study area are relatively dilute (dissolved-solids concentrations range from 212 to 953) and are Na$\mathrm{HCO}_{3}-\mathrm{SiO}_{2}$ type waters. Values of $\mathrm{pH}$ range from 6.6 to 9.6. This chemistry compares favorably with the analyses of thermal waters from the Idaho batholith (Young, 1985). Chloride values range from 6.5 to $79.0 \mathrm{mg} / \mathrm{l}$ and $\mathrm{SO}_{4}$ values range from 38 to $76 \mathrm{mg} / \mathrm{l}$.

Fluoride concentrations are high (up to $17 \mathrm{mg} / 1$ ) and exceed drinking water standards $(4 \mathrm{mg} / \mathrm{l})$ established by the U.S. Environmental Protection Agency (EPA). Elevated fluoride ingested over a period of time causes the breakdown of teeth and bone. Tooth enamel is affected by fluoride intake during its formation, but bones can be affected over an animal's life span (Oison and others, 1979). Chronic fluoride toxicosis has been found in ungulates in southwestern Idaho in the Bruneau-Grand View area and central Idaho (Shupe, personal communication, 1987). Olson and others (1979) found fluorisis in the wildlife at yellowstone National Park. Fluoride values ranged from $0.5 \mathrm{mg} / 1$ to $24 \mathrm{mg} / \mathrm{l}$ in the thermal springs and from $10 \mathrm{mg} / 1$ to $430 \mathrm{mg} / \mathrm{l}$ in vegetation and soils surrounding the thermal springs. They suggested that the wildlife were attracted to the springs during the winter and by the salt content and mineral supplement.

Concern was raised in the Warm Springs Creek area in Ketchum by residents who found elevated fluoride levels in their domestic water supply (Burkett and Litke, 1989). This contamination was caused by either the natural subsurface flow of hot water or by leaks in an existing hot water delivery pipe. Further development of the hot water and subsequent disposal into existing waterways has been discouraged by the Idaho Department of Health and Welfare, Division of Environment. The environmental consequences of the utilization of the hot water must be addressed before further development can take place.

Source of Fluoride and other Elements

Eight rocks, representative of outcrops at or near the thermal occurrences, were sampled for major and selected trace elements. The major element and trace element data are found in Table 4. Analyses were done by inductively coupled plasma spectrometry at the University of Utah Research Institute.

Foley and Street (1988) presented several fluoride analyses of rocks and minerals from central Idaho. These data are combined with the analyses conducted for this study and are found in Table 5. It is probable that the intrusive rocks are the major source of fluoride, and not the sedimentary rocks, even though most springs issue from the Paleozoic sedimentary units. It is interesting to 
TABLE 4. WHOLE-ROCK ANALYSES OF SELECTED ROCKS FROM THE BIG WOOD RIVER AREA, IDAHO

(Oxides in weight $\%$, trace elements in parts per million)

\begin{tabular}{|c|c|c|c|c|c|c|c|c|c|c|c|c|c|c|c|c|c|c|}
\hline Sample/location & $\mathrm{SiO}_{2}$ & $\mathrm{Al}_{2} \mathrm{O}_{3}$ & $\mathrm{TiO}_{2}$ & Mno & Mgo & $\mathrm{Fe}_{2} \mathrm{O}_{3}$ & $\mathrm{FeO}$ & $\mathrm{CaO}$ & $\mathrm{NaO}$ & $\mathrm{P}_{2} \mathrm{O}_{5}$ & $\mathrm{~K}_{2} \mathrm{O}$ & $L i$ & $B$ & As & $2 n$ & $\mathrm{~Pb}$ & $2 r$ & $\mathrm{Ce}$ \\
\hline $\begin{array}{l}\text { Warfield \#1 - near Warfield } \\
\text { Hot Springs (granitic intrusion) }\end{array}$ & 70.50 & 15.53 & .38 & .06 & .80 & 1.13 & 1.63 & 2.17 & 3.74 & .14 & 3.84 & 25 & $<400$ & $<25.0$ & 107 & 21 & 46 & 105 \\
\hline $\begin{array}{l}\text { Warfield } \$ 2 \text { - Paleozoic limestone at } \\
\text { Warfield Hot Spring (whole rock) }\end{array}$ & 51.70 & 3.22 & .21 & .05 & 3.05 & .23 & .73 & 40.44 & .08 & .08 & .48 & 8 & $<400$ & $<25.0$ & 88 & 25 & 179 & 31 \\
\hline $\begin{array}{l}\text { Tertiary granitic intrusion olong } \\
\text { Norton Creek (whole rock) }\end{array}$ & 64.30 & 15.74 & .54 & .07 & 2.77 & 1.64 & 2.67 & 3.42 & 4.54 & .19 & 3.41 & 18 & $<400$ & $<25.0$ & 78 & 28 & 114 & 81 \\
\hline $\begin{array}{l}\text { Tertiary Challis volcanic extrusion } \\
\text { near Russian John Hot Springs (whole } \\
\text { rock) }\end{array}$ & 63.40 & 16.56 & .64 & .08 & 2.31 & 1.98 & 2.70 & 3.91 & 4.42 & .20 & 3.26 & 20 & $<400$ & $<25.0$ & 76 & 19 & 326 & 81 \\
\hline $\begin{array}{l}\text { Hood River Conglomerate near Croy } \\
\text { Creck bridge west of Hafley (whole } \\
\text { rock) }\end{array}$ & 79.40 & 9.08 & .58 & .01 & .55 & 1.99 & .58 & 1.74 & .04 & .17 & 2.99 & 17 & $<400$ & $<25.0$ & 35 & $<10$ & 150 & 49 \\
\hline $\begin{array}{l}\text { Hailey Hot Springs - limestone } \\
\text { outcrop on hill west of spring } \\
\text { (whole rock) }\end{array}$ & 4.24 & .54 & .07 & .01 & 1.08 & .32 & .10 & 51.28 & .02 & .03 & .30 & 2 & $<400$ & $<25.0$ & 15 & 13 & 163 & 28 \\
\hline $\begin{array}{l}\text { Granite in road cut near Magic Hot } \\
\text { Springs landing (whole rock) }\end{array}$ & 66.80 & 15.08 & .71 & .08 & 2.20 & 1.77 & 2.22 & 4.62 & 3.38 & .21 & 2.75 & 38 & $<400$ & 54 & 77 & 15 & 9 & 77 \\
\hline $\begin{array}{l}\text { Precipitate from Magic Hot Springs } \\
\text { landing well (whole rock) }\end{array}$ & 38.80 & .10 & .01 & .04 & .44 & .21 & .04 & 13.06 & 20.42 & .02 & .75 & 477 & $<400$ & $<25.0$ & 103 & $\begin{array}{c}151 \\
0\end{array}$ & $<5.0$ & 18 \\
\hline
\end{tabular}


TABLE 5. FLUORIDE IN ROCKS AND MINERALS FROM CENTRAL IDAHO

\begin{tabular}{|c|c|}
\hline Sample and Location & $\begin{array}{l}\text { Fluoride conc., } \\
\text { in ppm }\end{array}$ \\
\hline $\begin{array}{l}\text { Challis Volcanics, west of Hailey } \\
\text { Hot Springs (whole rock) (1) }\end{array}$ & 540 \\
\hline $\begin{array}{l}\text { Paleozoic quartzite, adjacent to } \\
\text { Hailey Hot Springs (whole rock) (1) }\end{array}$ & 510 \\
\hline $\begin{array}{l}\text { Paleozoic Iimestone, adjacent to } \\
\text { Hailey Hot Springs (whole rock) (1) }\end{array}$ & 230 \\
\hline $\begin{array}{l}\text { Paleozoic limestone, adjacent to } \\
\text { Guyer Hot Springs (whole rock) (1) }\end{array}$ & 210 \\
\hline $\begin{array}{l}\text { Tertiary volcanics, near Magic Hot } \\
\text { springs (whole rock) (1) }\end{array}$ & 330 \\
\hline $\begin{array}{l}\text { Eocene granodiorite, clarendon stock near } \\
\text { clarendon Hot Springs (whole rock) (1) }\end{array}$ & 730 \\
\hline $\begin{array}{l}\text { Biotite from Eocene granodiorite, } \\
\text { Clarendon stock near Clarendon H.S. (1) }\end{array}$ & 3,700 \\
\hline Biotite from Cretaceous granodiorite (2) & 9,000 \\
\hline Biotite from sawtooth batholith (2) & 37,000 \\
\hline Warfield \#I near Warfield H.S. (whole rock) (3) & 430 \\
\hline $\begin{array}{l}\text { Warfield } \# 2 \text {, Paleozoic limestone at warfield } \\
\text { Hot springs (whole rock) (3) }\end{array}$ & 200 \\
\hline $\begin{array}{l}\text { Tertiary granitic intrusion along Norton Creek } \\
\text { (whole rock) (3) }\end{array}$ & 290 \\
\hline $\begin{array}{l}\text { Tertiary Challis volcanic extrusion near Russian } \\
\text { John Hot springs (whole rock) (3) }\end{array}$ & 510 \\
\hline $\begin{array}{l}\text { Wood River conglomerate near Croy Creek } \\
\text { Bridge west of Hailey (whole rock) (3) }\end{array}$ & 320 \\
\hline $\begin{array}{l}\text { Granitic intrusion near Magic Hot springs Landing } \\
\text { (whole rock) ( } 3 \text { ) }\end{array}$ & 480 \\
\hline $\begin{array}{l}\text { Hailey Hot Springs - limestone outcrop on hill } \\
\text { west of spring (whole rock) (3) }\end{array}$ & 20 \\
\hline $\begin{array}{l}\text { Precipitate from Magic Hot springs landing } \\
\text { well (whole rock) (3) }\end{array}$ & 1,700 \\
\hline
\end{tabular}

(1) Foley, D. and Street, Leah V., 1988, Hydrothermal Systems of the Wood River area, Laho, in Link, P.K., and Hackett, W.R., editors, Guidebook to the Geology of Central and Southern Idaho: Waho Geological Survey Bulletin 27, p. $109-126$.

(2) Bennett, E.H. and Knowles, C.R., 1985, Tertiary plutons and related rocks in Central ldaho, in Mclntyre, D.H., editor, Symposium on the geology and mineral deposits of the Challis $1 \times 2$-degree quadrangle, Idaho: US Geological Survey Bulletin 1658, Chapter F. p. 81-95.

(3) Street, Leah V., this paper. 
note that the precipitate taken from the Magic Hot Springs Landing well has extremely high fluoride content (1700 ppm). Perhaps fluoride is concentrated in the precipitate and not released as a vapor. With the high calcium content, it is also possible that the fluoride is precipitating as fluorite.

\section{Minor Constituents}

Values were obtained for arsenic, lithium and boron in water (Tables 2 and 3 ) and rocks (Table 4). Arsenic values above 50 micrograms/liter are considered harmful by the U.S. Environmental Protection Agency (1976). Concentrations in the thermal springs range from less than 1 to 4 micrograms/liter, whereas they are less than 1 microgram/liter in the cold springs: Except for the intrusive rock near Magic Hot springs Landing that had a concentration of $54 \mathrm{ppm}$, all other rocks had values less than 25 ppm arsenic.

The source of arsenic in the waters can be from volcanic gasses, oxidation of arsenopyrite (FeAsS) or from pesticides (Hem, 1985). It is doubtful that pesticides are the source of the arsenic found in these waters. Based upon the rock geochemistry, the probable source is the intrusion.

Lithium values range from 2 to $38 \mathrm{ppm}$ in the sampled rocks with the higher values being found in the volcanics. values of 95 to 1300 micrograms/liter were found in the thermal water samples. Lithium can be toxic to plants (Hem, 1985).

Lithium-bearing minerals are found in lithium-rich pegmatites (Deer and others, 1966). Pegmatites are associated with the Idaho Batholith and its associated plutons (Bennett and Knowles, 1985). Even though pegmatites were not found near the hot springs, deep circulation and contact with the lithium-rich dikes at depth could be the source. There is limited data on the lithium content of volcanic rocks.

Boron values in the thermal waters range from 100 to 1,100 micrograms/liter) and, in the cold waters, from less than 10 to 30 micrograms/liter. The rocks have less than $400 \mathrm{ppm}$.

Boron can be harmful to citrus trees, in particular. The source for the boron can either be granitic rocks, pegmatites or volcanic gasses. It can also be an accessory constituent of biotite and amphibole (Hem, 1985).

Geothermometry

Geochemical thermometers have been used to estimate subsurface equilibrium temperatures for thermal waters. The silica (Fournier and Rowe, 1966) and the $\mathrm{Na}-\mathrm{K}-\mathrm{Ca}$ (Fournier and Truesdell, 1973) are the two most widely used. For the results to be valid, certain 
assumptions must be met: 1) the chemical reactions at the subsurface are temperature-dependent, 2) concentrations of the selected chemical constituents used in the formulae are sufficient, 3) chemical equilibrium between the hot water and specific aquifer minerals exists, 4) as the hot water rises to the surface any reequilibration is minute, and 5) the hot water rises rapidly to the surface with no mixing with other hot or cold waters (White, 1970).

Reservoir temperatures calculated by Young (1985), using both the silica and the $\mathrm{Na}-\mathrm{K}-\mathrm{Ca}$ geothermometer for batholith-associated hot waters were similar. Because water in the study area, excluding Magic Hot Springs Landing, is chemically similar to the batholith thermal waters, only the $\mathrm{Na}-\mathrm{K}-\mathrm{Ca}$ geothermometer was used. For Magic Hot springs Landing, the Mg correction (Fournier and Potter, 1979) was applied to the $\mathrm{Na}-\mathrm{K}-\mathrm{Ca}$ geothermometer. The silica geothermometer was also calculated for Magic Hot springs Landing because the $\mathrm{pH}$ is low and meets the requirements of the calculations. The results are found in Table 2 .

Isotopes

The isotopes of deuterium and oxygen-18 are useful in hydrology for determining origin and flowpaths. A comparison to the standard mean ocean water (SMOW) (Craig, 1961) can indicate whether waters have been in the hydrologic cycle previously or are magmatic or juvenile. The relative enrichment of deuterium and $0^{18}$ in ocean water is greater than in fresh water because during evaporation the heavier molecules become enriched in the residual water and the lighter molecules are found in water vapor, rain, snow and most fresh water (Hem, 1985).

Craig (1961) constructed the meteoric water Iine $\left(\delta \mathrm{D}=8 \delta^{18} \mathrm{O}\right.$ +10 (SMOW)) based upon a world wide study of fresh water samples. This line is plotted on both Figures 3 and 4 .

The deuterium contents of the recharge fluids and precipitation are commonly retained by both thermal and nonthermal groundwater during passage through an aquifer. Water-rock reactions do not affect the concentrations of deuterium and $0^{18}$ (Ellis and Mahon, 1977).

To determine the characteristics of the thermal water in the study area, five samples of cold springs and seven samples of hot springs or wells were taken. The results are shown in Table 6 . Foley and street (1988) analyzed five hot springs for isotopic composition and Mitchell, in Anderson and Bideganeta (1985) sampled eight hot springs and seven cold water sites. The results of the present study replicate the 1988 study of Foley and street and are also in agreement with similar water analyses in the batholith area as reported by Young (1985). 


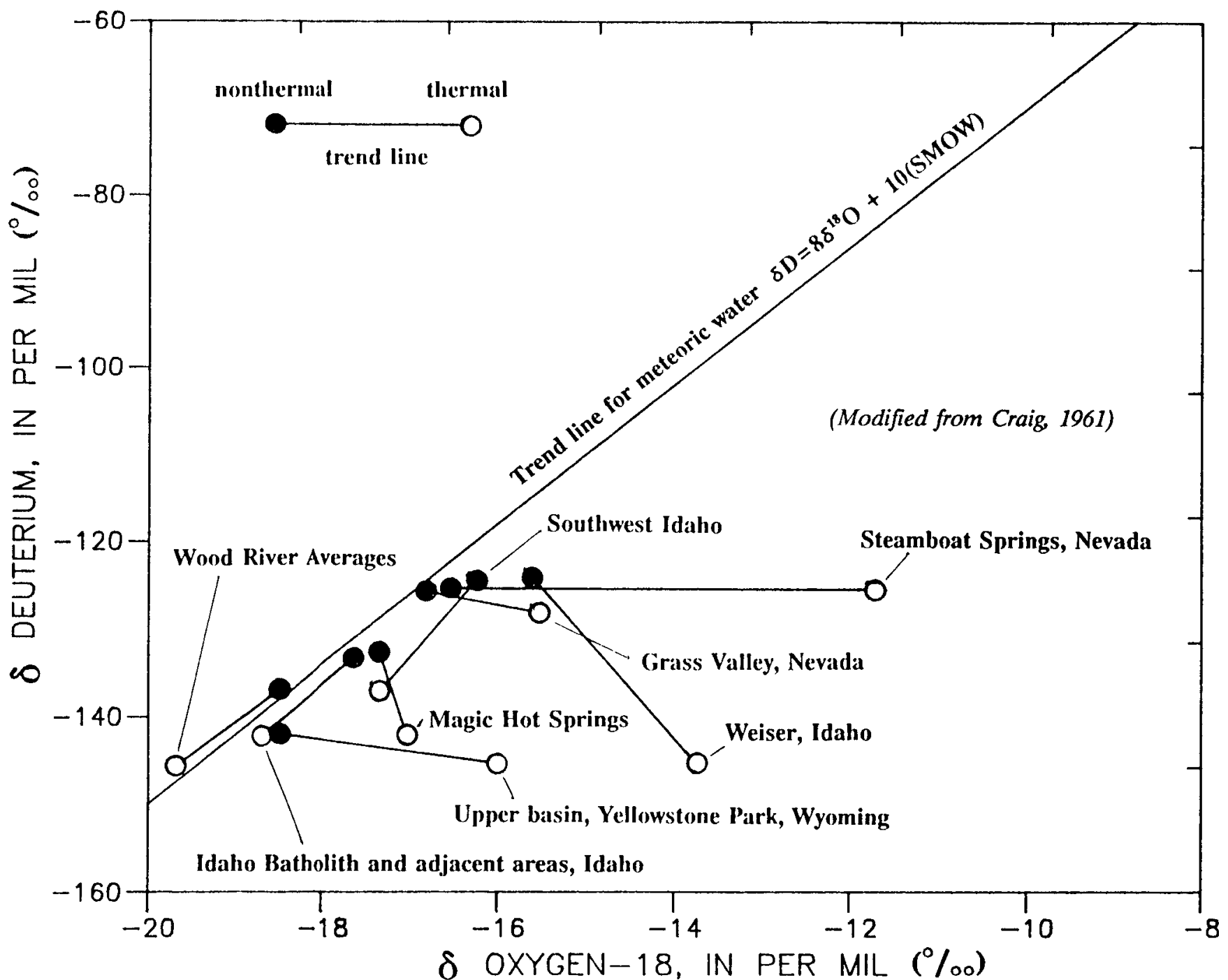

FIGURE 3.--Comparison of isotopic composition of non-thermal and thermal waters in Idaho, Wyoming, and Nevada. 


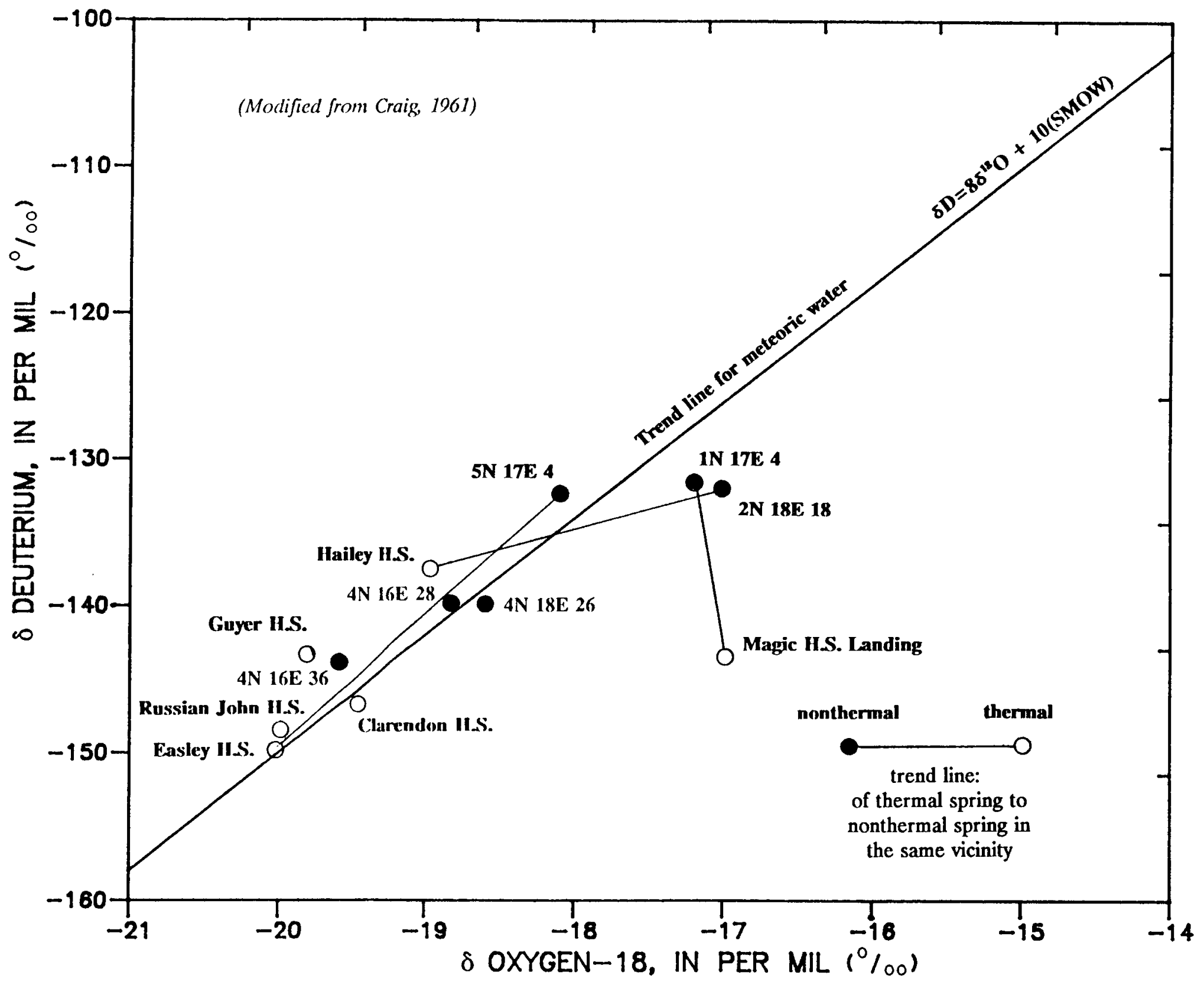

FIGURE 4. - Relation between concentrations of deuterium and oxygen-18 for selected thermal springs and adjacent high-altitude nonthermal springs. 
TABLE 6. DEUTERIUM AND OXYGEN-18 VALUES

\begin{tabular}{|l|l|l|l|l|}
\hline Site & Location & $\begin{array}{c}\text { Temp., } \\
{ }^{\circ} \mathrm{C} .\end{array}$ & $\mathrm{D}$ & $0^{18}$ \\
\hline
\end{tabular}

Magic Hot Springe Landlng

Halley Hot springs

clarendon Hot springo

Guyer Hot Springe

Warfleld Hot Springs

Russian John Hot Springs

Easley Hot Springa

Lambs Gulch Springs

Headquarters spring

Trlumph spring

Forest service spring

Blilingsley Cold spring
O1S 17E 23AABI

O2N 18E 18DBB1

O3N 17E 27DCB 1

04N 17E 15AAC1

04N 16E 36AAC1

06N 16E 33CCA1

05N 16E 1ODBC1

O2N 18E 18BBA1

05N 17E 04AAA1

04N 18E 26BBC1

04N 16E 28DAC1

01N 21E 14BDD1S
74.5

60.0

47.0

70.5

58.5

34.0

37.5

8.5

7.0

8.0

12.5

10.0
$-143$

$-142$

$-147$

$-144$

$-144$

$-149$

$-150$

$-132$

$-134$

$-140$

$-140$

$-131.0$
$-17.0$

$-19.0$

$-19.5$

$-19.8$

$-19.6$

$-20.0$

$-20.0$

$-17.0$

$-18.1$

$-18.6$

$-18.8$

$-17.4$ 
Values obtained for this study are plotted on Figure 3 along with vaiues from other sites in Idaho, Wyoming, and Nevada (roung, 1985). The deuterium values for the local recharge waters are similar to sites in Nevada and Wyoming; oxygen-18 is significantly enriched in these waters and in Magic Hot springs and Weiser, Idaho. This enrichment is probably caused by the higher temperatures at these sites. The depletion of oxygen-18 in the study area is similar to the batholith thermal sites, suggesting that the water is not derived from current precipitation as concluded by Young (1985) and Young and Lewis (1982a).

Figure 4 compares the values from thermal waters with higherelevation cold springs. The deuterium values for the thermal springs are depleted relative to the values obtained for the cold springs. This is in agreement with Young (1985) who concluded that the thermal waters in the batholith were recharged in the past when the climates were cooler and precipitation was greater than the present or that recharge took place from higher-elevation precipitation.

\section{SUMMARY}

The Wood River area hydrothermal resources are dilute $\mathrm{Na}-\mathrm{HCO}_{3}-$ $\mathrm{SiO}_{2}$ type waters. Calculated reservoir temperatures using geothermometry are under $100^{\circ} \mathrm{C}$. except for the Magic Hot springs Landing well at $187^{\circ} \mathrm{C}$. $\left(108^{\circ} \mathrm{C}\right.$. with $\mathrm{Mg}$ correction) (Fournier and Potter, 1978). The chemistry and temperature recorded at this site is anomalous compared to the other wood River area thermal springs. The higher temperatures at depth may have resulted in the higher total dissolved content of this water.

The depletion in deuterium relative to oxygen-18 implies that the thermal water is not derived from present day precipitation, or from higher-elevation precipitation, but that the water fell as precipitation when the climate was much colder and wetter.

Comparison of the anion to cation ratios and the trace element concentrations of the thermal springs to the rocks and minerals exposed in the area, suggests that the thermal waters have a chemical affinity to the cretaceous and Tertiary intrusions and not the Paleozoic sedimentary rocks. Further, the intrusions crop out on the more faulted west side, which is where the springs occur. The intrusive rocks could have caused faulting during emplacement. These intrusions are also the suspected source of the high fluoride and arsenic concentrations found in the thermal waters. 


\section{SELECTED REFERENCES}

Anderson, A.L., and Wagner, W.R., 1946, A geological reconnaissance of the Hailey gold belt (Camas district), Blaine county, Idaho: Idaho Bureau of Mines and Geology Pamphlet 76, 26 p.

Anderson, A.L., Kiilsgaard, T.H., and Fryklund, V.C., Jr., 1950, Detailed geology of certain areas in the Mineral Hill and Warm Springs mining districts, Blaine county, Idaho: Idaho Bureau of Mines and Geology Pamphlet $90,73 \mathrm{p}$.

Anderson, J.E., and Bideganeta, K., 1985, A preliminary geologic reconnaissance of the geothermal occurrences of the Wood River drainage area: Idaho Department of Water Resources Water Information Bulletin 30, Part 13, 49 p.

Batchelder, J.N., and Hall, W.E., 1978, Preliminary geologic map of the Hailey 7.5-minute quadrangle, Idaho: U.S. Geological Survey open-File Report 78-546, scale 1:24,000.

Bennett, E.H., and Knowles, C.R., 1985, Tertiary plutons and related rocks in central Idaho, in McIntyre, D.H., editor, Symposium on the geology and mineral deposits of the challis $1 \times 2$ degree quadrangle, Idaho: U.S. Geological Survey Bulletin 1658, Chapter F, p. 81-95.

Blackett, R.E., 1981, Preliminary investigation of the geology and geothermal resources at Guyer Hot springs and vicinity, Blaine County, Idaho: University of Utah Research Institute, Earth Science Laboratory open-File Report ID/GHS/ESL-1, 24 p.

Bonnichsen, B., Leeman, W.P., Jenks, M.D., and Honjo, N., 1988, Geologic field trip guide to the central and western snake River Plain, emphasizing the silicic volcanic rocks, in Link, P.K., and Hackett, W.R., editors, Guidebook to the geology of central and southern Idaho: Idaho Geologic Survey Bulletin 27, p. 247-281.

Brott, C.A., Blackwell, D.D., and Mitchell, J.C., 1976, Heat flow study of the Snake River Plain region, Idaho: Idaho Department of Water Resources Water Information Bulletin 30, part 8, 195 p.

Brott, C.A., Blackwell, D.D., and Ziagos, J.P., 1981, Thermal and tectonic implications of heat flow in the eastern snake River Plain, Idaho: Journal of Geophysical Research, v. 86, p.1170911734 .

Burkett, Gary R. and Litke, R. Tim, 1989, Warm springs creek Geothermal study: Idaho Department of Health and Welfare, Division of Environmental Quality, water Quality status Report No. 84, $76 \mathrm{p}$. 
Castelin, P.M., and Chapman, S.L., 1972, water resources of the Big wood River-Silver Creek area, Blaine county, Idaho: Idaho Department of Water Administration Water Information Bulletin 28 , $44 \mathrm{p}$.

Castelin, P.M. and Winner, J.E., 1975, Effects of urbanization on the water resources of the Sun Valley-Ketchum area, Blaine County, Idaho: Idaho Department of Water Resources Bulletin 40,86 p.

Craig, H., 1961, Isotopic variations in meteoric waters: Science, v. 133, p. 1702-1703.

Deer, W.A., Howie, R.A., and Zussman, J., 1966, An introduction to the rock-forming minerals: Longman Group Ltd., London, 528 p.

Ellis, A.J. and McMahon, W.A.J., 1977, Geochemistry and Geothermal Systems, New York, Academic Press, 392 p.

Foley, D., and street, L.V., 1985, Geothermal systems of the Snake River Plain, Idaho batholith and northern Rocky Mountain transition zone: Geological Society of America Abstracts with Programs, v. 17, p. 218-219.

Foley, D., and street, L.V., 1986, High fluoride in geothermal waters from Idaho: Geological society of America Abstracts with Programs, v. 18, p. 604 .

Foley, D., and Street, L.V., 1988, Hydrothermal systems of the wood River area, Idaho, in Link, P.K., and Hackett, W.R., editors, Guidebook to the Geology of central and Southern Idaho: Idaho Geological Survey Bulletin 27, p. 109-126.

Foley, D., Zeisloft, J., and Blackett, R.E., 1983, Hydrothermal systems of the Wood River district, Idaho: Geological Society of America Abstracts with Programs, v. 15, p. 416.

Fournier, R.O., and Rowe, J.J., 1966, Estimation of underground temperatures from the silica content of water from hot springs and wet steam wells: American Journal of Science, v. 264, p. 685-695.

Fournier, R.O., and Truesdell, A.H., 1973, An empirical Na-K-Ca geochemical thermometer for natural waters: Geochim, et. Cosmochim, Acta., v. 73, p. 1255-1275.

Fournier, R.O., and Potter, R.W., II, 1978, A magnesium correction for the $\mathrm{Na}-\mathrm{K}-\mathrm{Ca}$ chemical geothermometer: U.S. Geological Survey Open-File Report 78-986, 24 p.

Fournier, R.O., White, D.E., and Truesdell, A.H., 1974, Geochemical indicators of subsurface temperature, Part 1, basic assumptions: U.S. Geological Survey Journal of Research, v. 2, p. 259-262. 
Frenzel, S.A.,1989, Water resources of the upper Big Wood River basin, Idaho: U.S. Geological Survey Water-Resources Investigations Report 89-4018, $47 \mathrm{p}$.

Hall, W.E., 1985, Stratigraphy of and mineral deposits in middle and upper Paleozoic rocks of the black-shale mineral belt, central Idaho, in McIntyre, D.H., editor, symposium on the geology and mineral deposits of the Challis $1 \times 2$ degree quadrangle, Idaho: U.S. Geological Survey Bulletin 1658, Chapter J., p. 117-131.

Hall, W.E. and McIntyre, D.H., 1986, Eocene cauldron, batholith, and hydrothermal alteration east of Ketchum, Idaho: U.S. Geological Survey Open-File Report 86-0122, 5 p.

Hall, W.E., Batchelder, J.N., and Douglass, R.C., 1974, Stratigraphic section of the wood River Formation, Blaine county, Idaho: U.S. Geological Survey Journal of Research, v. 2, p. 89-95.

Hall, W.E., Rye, R.O., and Doe, B.R., 1978, wood River mining district, Idaho-intrusion-related lead-silver deposits derived from country rock source: U.S. Geological Survey Journal of Research, v. 6 , p. 579-592.

Hem, J.D., 1985, study and interpretation of the chemical characteristics of natural water: U.S. Geological Survey waterSupply Paper 2254, 263 p.

Henley, R.W, and A.J. Ellis, 1983, Geothermal systems ancient and modern: a geochemical review: Earth-Science Review, v. 19, p. 1-50.

Howard, K.A., and 12 others, 1978, Preliminary map of young faults in the United States as a guide to possible fault activity: U.S. Geological Survey Map MF-916.

Johnson, K.M, Lewis, R.S., Bennett, E.H., and Kiilsgaard, T.H., 1988, cretaceous and Tertiary intrusive rocks of south-central Idaho, in Link, P.K., and Hackett, W.R., editors, Guidebook to the geology of central and southern Idaho: Idaho Geological Survey Bulletin 27, p. 55-86.

Leeman, W.P., 1982, Geology of the Magic Reservoir area, Snake River Plain, Idaho, in Bonnichsen, Bill, and Breckenridge, R.M., editors, Cenozoic geology of Idaho: Idaho Bureau of Mines and Geology Bulletin 26, p. 369-376.

Link, P.K., Mahoney, J.B., Burton, B.R., Ratchford, M.E., Turner, R.J.W., and otto, B.R., 1987, Introduction to the geology of central Idaho black shale mineral belt: Northwest Geology, $v$. 16, p. 61-84. 
Link, P.K., Skipp, B.A., Hait, M.H.,Jr., Janecke, S., and Burton, B.R, 1988, structural and stratigraphic transect of south-centrai Idaho: a field guide to the Lost River, White Knob, Pioneer, Boulder, and Smoky Mountains, in Link, P.K., and Hackett, W.R., editors, Guidebook to the geology of central and southern Idaho: Idaho Geological Survey Bulletin 27, p. 5-42.

Mariner, R.H., Brook, C.A., Reed, M.J., Bliss, J.D., Rapport, A.L., and Lieb, R.J., 1983, Low-temperature geothermal resources in the western United States, in Reed, M.J., editor, Assessment of lowtemperature geothermal resources of the United States - 1982: U.S. Geological survey Circular 892, p. 31-50.

Mitchell, J.C., 1976, Geochemistry and geologic setting of the thermal waters of the Camas Prairie area, Blaine and camas Counties, Idaho: Idaho Department of water Resources water Information Bulletin 30, Part 7, $44 \mathrm{p}$.

Mitchell, J.C., Johnson, L.L., and Anderson, J.E., 1980, Potential for direct heat application of geothermal resources: Idaho Department of Water Resources Water Information Bulletin 30, Part $9,396 \mathrm{p}$.

Olson, A.E., Peterson, H.B. and Shupe, J.L., 1979, Chronic fluoride toxicosis in wildlife in Yellowstone National Park: Second Conference on Scientific Research in the National Parks, p. 294302 .

Otto, B.R., and Turner, R.J.W., 1987, stratigraphy and structure of the Milligen Formation, Sun Valley area, Idaho: Northwest Geology, v. 16 , p. 95-103.

Rember, W.C., and Bennett, E.H., 1979, Geologic map of the Hailey 2-degree quadrangle, Idaho: Idaho Bureau of Mines and Geology, scale $1: 250,000$.

Sammel, E.A., 1979, Occurrence of low-temperature geothermal waters in the United States, in Muffler, L.J.P., editor, Assessment of geothermal resources of the United States-1978: U.S. Geological Survey Circular 790, p. 86-131.

Sandberg, C.A., Hall, W.E., Batchelder, J.N., and Axelsen, C., 1975, Stratigraphy, conodont dating, and paleotectonic interpretation of the type Milligen Formation (Devonian), Wood River area, Idaho: U.S. Geological Survey Journal of Research, v. 3 , p. 707-720.

Skipp, Betty, 1987, Basement thrust sheets in the clearwater orogenic zone, central Idaho and western Montana: Geology, v. 15, p. 220-224. 
Skipp, Betty, and Hait, M.H., Jr., 1977, Allochthons along the northeast margin of the Snake River Plain, Idaho, in Heisey, E.L., Lawson, D.E., Norwood, E.R., Wach, P.H., and Hale, L.A., editors, Rocky Mountain thrust belt geology and resources: Wyoming Geological Association 29th Annual Field Conference, p. 499-515.

Smith, R.O., 1959, Ground-water resources of the Middle Big Wood River-Silver Creek area, Blaine County, Idaho: U.S. Geological Survey Water-Supply Paper $1478,61 \mathrm{p}$.

Struhsacker, D.W., Jewell, P.W., Zeisloft, Jon, and Evans, S.H., Jr., 1982, The geology and geothermal setting of the Magic Reservoir area, Blaine and Camas Counties, Idaho, in Bonnichsen, Bill and Breckenridge, R.M., editors, Cenozoic geology of Idaho: Idaho Bureau of Mines and Geology Bulletin 26, p. 377-393.

Umpleby,J.B., Westgate, L.G., and Ross, C.P., 1930, Geology and ore deposits of the wood River region, Idaho: U.S. Geological SurveY Bulletin $814,250 \mathrm{p}$.

U.S. Environmental Protection Agency, 1976, Quality Criteria for Water, 1976: Washington, D.C., Government Printing office, 256 p.

Walton, W.C., 1962, Ground-water resource of Camas Prairie, camas and Elmore Counties, Idaho: U.S. Geological Survey Water-Supply Paper 1609, $55 \mathrm{p}$.

Wavra, C.S., Isaacson, P.E., and Hall, W.E., 1986, studies of the Idaho black shale belt: stratigraphy, depositional environment, and economic geology of the Permian Dollarhide Formation: Geological Society of America Bulletin, v. 97, p. 1504-1511.

White, D.E., 1970, Geochemistry applied to the discovery, evaluation, and exploitation of geothermal energy resources, in Proceedings, United Nations Symposium on the Development and Utilization of Geothermal Energy, Pisa; v. 1, Part 2, Geothermics, Special Issue 2, p. 58-80.

Wust, S.L., 1986, Extensional deformation with northwest vergence, Pioneer core complex, central Idaho: Geology, v. 14, p. $712-714$.

Young, H.W., and Lewis, R.E., 1982a, Hydrology and Geochemistry of thermal ground water in Southwestern Idaho and North-Central Nevada: U.S. Geological Survey Professional Paper 1044-J, 20 p.

Young, H.W., and Lewis, R.E., 1982b, Thermal springs in the Salmon River Basin, central Idaho: U.S. Geological survey open-file Report 82-0104, $30 \mathrm{p}$.

Young, H.W., 1985, Geochemistry and hydrology of thermal springs in the Idaho batholith and adjacent areas, central Idaho: U.S. Geol. Survey Water Resources Investigations Report 85-4172, $41 \mathrm{p}$. 
Zeisloft, Jon; Foley, Duncan; and Blackett, R.E., 1983, Water geochemistry of hydrothermal systems, wood River district, Idaho: Earth Science Laboratory/University of Utah Research Institute Report No. 124, DOE/ID/12079-107, 20 p. 


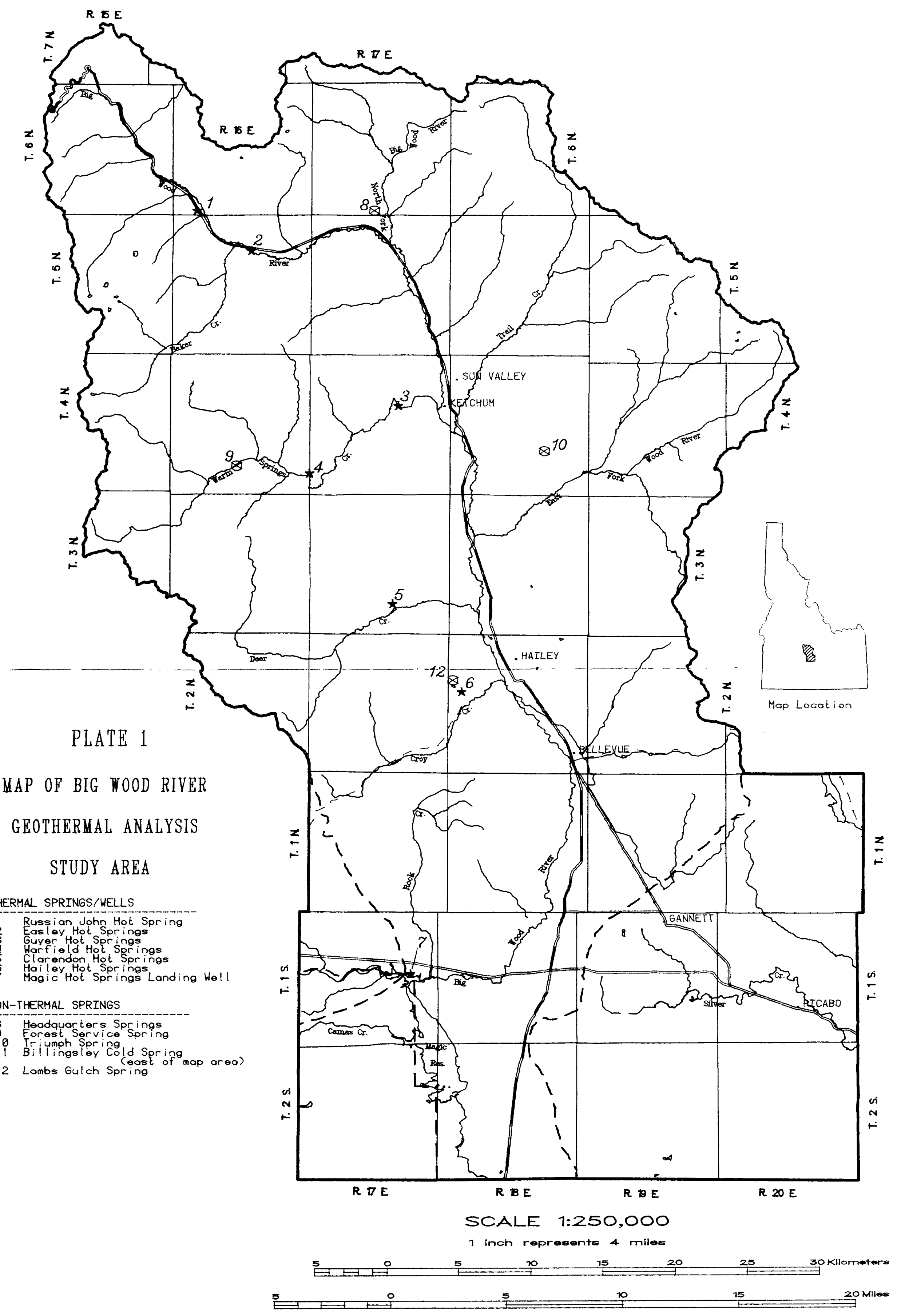

